DOI: https://doi.org/10.17979/rgf.2009.10.0.3925

\title{
Lingua galega e preconcepto
}

\author{
Xosé Ramón Freixeiro Mato \\ Universidade da Coruña
}

\begin{abstract}
Resumo:
Neste artigo defínese o preconcepto en relación con outras nocións afíns, centrándose logo o traballo no estudo do preconcepto lingüístico como manifestación do racismo aplicado ás linguas e aos seus falantes. Após unha aproximación aos preconceptos lingüísticos no mundo desde unha perspectiva histórica e ás tentativas da súa clasificación a nivel xeral, estúdase a súa xénese e evolución na sociedade galega. A seguir, agrúpanse para a súa análise en preconceptos relacionados coa suposta falta de utilidade do galego, os que asocian este co atraso e a pobreza, os que consideran o seu uso como sinal de descortesía ou má educación, aqueles relacionados coa pretensa imposición lingüística, os referidos á caracterización pexorativa da lingua e a competencia dos falantes, e por último os que se refiren ao galego como marca ideolóxica ou profesional.
\end{abstract}

\section{Palabras chave:}

Preconcepto lingüístico, lingua galega, racismo lingüístico, imposición.

\begin{abstract}
:
In this article prejudice is defined along with other related concepts, and next the work concentrates on the study of linguistic prejudice as a manifestation of racism applied to the languages and their speakers. After an approximation to the linguistic prejudices in the world from an historical perspective and to the attempts at classification in a general level, their genesis and evolution are studied in the Galician society. Next, they are grouped for analysis in prejudices related with a supposed lacking of utility of Galician; those that associate this with delay and poverty; those that consider its use as a signal of impoliteness or bad education; those related with a supposed linguistic imposition; those referred to the pejorative characterization of the language and the competence of its speakers; and, finally, those that are referred to Galician as an ideological or professional mark.
\end{abstract}

\section{Key words:}

Linguistic prejudice, Galician language, linguistic racism, imposition. 


\section{Introdución}

Sobre o galego, igual que sobre calquera lingua en situación de minorización social, circularon discursos cargados de preconceptos ou prexuízos. Unha boa mostra de que, após máis de trinta anos de política lingüística na Galiza, non se conseguiu superar esa situación de minorización é a sobrevivencia de moitos deses preconceptos que secularmente viñeron operando e inclusivemente o aparecemento doutros novos nos últimos tempos. Xa dixera Albert Einstein que é máis difícil romper un preconcepto do que un átomo e isto estase a pór en evidencia no caso galego, onde mesmo a xente nova non se dá liberado deles (González 2003). E se esta situación non se logrou superar durante un período de políticas protectoras do galego, embora "de baixa intensidade" (Lorenzo 2005), difícil vai ser vencer os preconceptos que inviabilizan a normalización do galego nunha nova etapa en que se anuncian medidas regresivas e desprotectoras do idioma propio. Porén, o combate contra os preconceptos lingüísticos preséntase como un obxectivo ineludíbel para a sobrevivencia dunha lingua en perigo como o galego.

Cómpre distinguirmos os preconceptos doutras nocións relacionadas, como as actitudes, valores e, sobre todo, estereótipos, pois para que exista un preconcepto debe haber un estereótipo previo ${ }^{1}$. As actitudes, tanto individuais como sociais, teñen unha grande importancia, pois adoitan interpretarse como un factor explicativo, e por tanto preditivo, da conduta (Iglesias Álvarez 1999), de modo que o estudo de como se forman e como mudan pode converterse nun aspecto clave na resolución de conflitos individuais e sociais. As actitudes podémolas definir como construtos mentais, e por tanto internos, das persoas, que conducen a que estas respondan favorábel ou desfavorabelmente perante un obxecto dado. Están moi vinculadas ás ideoloxías, que embora interpretadas en ocasións só dun punto de vista negativo como lexitimadoras ou xustificadoras do poder estabelecido, na realidade poden ser tanto dominantes como de resistencia - ou contraideoloxías-. A grande importancia das ideoloxías radica en que guían a interpretación do mundo das persoas e condicionan o seu comportamento social; porén, posúen un nivel de xeneralidade e abstracción demasiado alto, de modo que é preciso distinguirmos no seu interior compoñentes máis específicas e concretas, a que chamamos actitudes. Así pois, o que distingue as actitudes das ideoloxías é simplemente o maior nivel de especificidade das primeiras, aínda que sempre pode haber actitudes illadas que non se integran en ningunha ideoloxía concreta. En canto as ideoloxías se forman sobre temas relevantes para un grupo coa función de defenderen os intereses deste -dominante ou dominado-, as actitudes posúense sobre calquera obxecto e situación. Os valores, por súa parte, diferéncianse das ideoloxías e das actitudes en que son partillados por toda unha

1 De acordo con Iglesias Álvarez (2003: 15-42), a quen fundamentalmente seguiremos nesta introdución. Véxase tamén Baker (1992), Bagno (2003), Leite (2008) ou Ninyoles (1997 e 2005). 
cultura, aínda que poida haber sectores desta que presenten valores desviados, feito que os converte en marxinais e rexeitados socialmente.

As ideoloxías, as actitudes, os valores, as normas sociais e o coñecemento sociocultural non son innatos, mais aprendidos, seguindo os mesmos principios de adquisición que outras formas de aprendizaxe. Os estereótipos, por súa parte, son construtos cognitivos que fan referencia aos atributos dun grupo social e poden conter características positivas e negativas. Polo xeral utilízanse de forma negativa para que certos grupos manteñan a súa posición dominante sobre outros, isto é, cumpren unha función defensiva. Aplicando isto ás linguas, asóciase unha determinada lingua cun status socioeconómico concreto e, en consecuencia, considérase a mudanza de idioma como un dos medios para modificar ese status. Desa forma, as linguas acaban por funcionar como capital social, cultural, económico e simbólico; e inclusive se percibe o poder que adquire unha lingua como unha característica inherente e non como algo conxuntural. Porén, a creación de estereótipos é necesaria xa que nos permiten simplificar o mundo que nos rodea para o podermos comprender. Os estereótipos forman, pois, parte do proceso de categorización, unha das principais funcións que tamén posúen as actitudes. Os estereótipos negativos son aqueles que van asociados a preconceptos e desembocan facilmente na discriminación.

Os preconceptos son, seguindo Iglesias (2003: 28), sentimentos afectivos de rexeitamento e a súa función é serviren para rexeitar o grupo máis débil, que se debe manter a distancia, e xustificaren a superioridade do grupo dominante. Existen preconceptos sobre os pretos, as mulleres, os vascos ou cataláns, a lingua galega etc., isto é, sobre aquilo que ameaza os grupos dominantes. En palabras de Bagno (2003: 12), os preconceptos son produto da intolerancia, principalmente cando esta é "fruto de uma visão de mundo estreita, inspirada em mitos e superstições que têm como único objetivo perpetuar os mecanismos de exclusão social". Preconcepto e intolerancia tamén aparecen ligados en Leite (2008: 20), pois o primeiro é definido como "a idéia, a opinião ou o sentimento que pode conduzir o indivíduo à intolerância”. A adquisición dos preconceptos prodúcese durante o proceso de socialización, en que a infancia e a adolescencia desempeñan un papel fundamental, a se converteren os pais e nais e o profesorado, xunto cos medios de comunicación -en especial a televisión- e o grupo de amizades, en principais axentes na súa formación. Transmítense sobre todo a través do discurso socialmente circulante, isto é, da información verbal, que é o medio de socialización por excelencia, xuntamente coa análise directa dos feitos; así, no caso do galego a propia experiencia adquirida a través da observación da conduta dos maiores pode convencer unha crianza de que este idioma non é válido para determinados usos.

Por outra parte, e seguindo Tuson(1990:22-27), convén distinguirmos os xuízos de valor dos xuízos de feito. Os primeiros poden someterse a comprobación, fundaméntanse na experiencia colectiva e non dan lugar a preconceptos, en tanto que os segundos 
non son comprobábeis, poden construírse ou non sobre un consenso, ofrecen indicios sobre os gostos persoais e sobre a educación recibida, expresan a actitude de quen os fai e costuman ser positivos ou negativos (gostar de/non gostar de, bonito/feo, ben/mal etc.). Os xuízos de valor poden afectar as persoas, os pobos, as linguas etc. con base en propiedades circunstanciais ou pemanentes -representan características esenciais de persoas e grupos humanos-. O problema é que, con frecuencia, os xuízos de valor adoptan fórmulas dos xuízos de feito e presentan como trazos negativos características inalienábeis de persoas e pobos -ser baixo, preto, muller...-, de modo que uns xuízos aparentemente descritivos se converten en discriminatorios. Por esta vía, os xuízos de valor poden conducir aos preconceptos sobre os pobos -por exemplo, sobre os escoceses, cataláns ou alemáns- e tamén sobre as linguas. Evidentemente, algúns dos xuízos de valor sobre as linguas están inducidos desde o poder, como cando se fala de linguas de cultura, linguas internacionais, linguas aptas para as leis ou a literatura etc. e, polo contrario, linguas que non serven para nada diso. Os preconceptos, en definitiva, son xuízos atrevidos ou precipitados emitidos sen base suficiente por persoas que se deixan levar por tendencias non sustentadas na razón.

\section{Os preconceptos lingüísticos e a súa clasificación}

O preconcepto lingüístico é unha subclase dos preconceptos e afecta tanto as linguas como os seus falantes. Pode ser definido como un medio para coñecermos, mediante a fala, as características do interlocutor: a súa orixe social -fala galego, por tanto é da aldea-, a educación -fala ben o español, por conseguinte é unha persoa que recibiu educación- etc. Neste sentido, a minusvaloración e abandono da lingua propia é consecuencia dun preconcepto lingüístico que mellor se podería denominar autopreconcepto, autoodio ou deslealdade lingüística (Tuson 1990: 29). Este concepto de autoodio (self-hatred) foi definido por Allport (1962: 172), seguindo as investigacións de Kurt Lewin, como o sentimento de vergoña que alguén pode ter por posuír as características -reais ou imaxinarias- que despreza no seu propio grupo. $\mathrm{O}$ autoodio produce como primeiro efecto a identificación cos intereses culturais do grupo dominante, o que provoca no individuo que o padece unha máis aguda sensibilidade a respecto da súa propia inferioridade e un impulso cara ao rexeitamento das características sociais e culturais do grupo a que pertence, entre elas o idioma. Desta forma, o grupo propio convértese en grupo de referencia negativa, perante o cal ese individuo non só se deberá mostrar indiferente, mais dependentemente hostil (Ninyoles 2005: 189).

Dunha forma ou doutra e en diferentes graos, para Tuson o preconcepto lingüístico é unha manifestación do racismo aplicado ás linguas e aos seus falantes, e pode producir inclusive a morte dunha lingua ao considerala menos apta do que outra. Este mesmo autor defíneo como 
unha desviación da racionalidade que ten a forma de xuízo de valor emitido ben sobre unha lingua (ou sobre algunha das súas características), ben sobre os falantes dunha lingua (en tanto que falantes), xerado directamente pola ignorancia ou pola malevolencia, axustado a estereotipos maniqueos e ditado pola molestia que nos producen as diferenzas (Tuson 1990: 30).

Moreno Cabrera (2006a: 15-16), por seu turno, fala de "prejuicios discriminatorios", de que non se libra nin a lingüística "más pura y objetiva", e toma como concepto básico o de 'discriminación lingüística', que define como calquera actitude cara ás linguas ou variedades que se basee na idea de que estas se poden clasificar en tipos e que existen diferenzas entre eses tipos "que pueden justificar la concepción de que unas son superiores a otras total o parcialmente".

Os preconceptos lingüísticos son case tan vellos como as propias linguas. Xa na antigüidade Sócrates criticaba os poetas por mudaren as palabras e Quintiliano describía o 'grammaticus' como posuidor da corrección lingüística ${ }^{2}$. $\mathrm{Na}$ Idade Media confrontábase o latín, lingua culta, cos romances ou linguas vulgares; e mesmo cara a finais do período se falaba de linguas boas ou más segundo tivesen ou non gramáticas. A comezos do século XIV Dante, en De vulgari eloquentia, xa deixa transparecer unha grande cantidade de preconceptos lingüísticos cando afirma que a lingua dos romanos é a peor de todas porque estes feden a bravún, que os de Aquilea arrotan ao falaren, que os dialectos do Lacio son femininos etc. No século XVI, o emperador Carlos - Carlos I de España e V de Alemaña, como nos aprenderon- deixou dito que utilizaba o castelán para falar con Deus, o francés para se comunicar cos amigos e o alemán para tratar cos inimigos -ou mesmo co cabalo segundo outras versións-. Se nos situarmos no século XVIII, acharemos que no volume IX da Encyclopédie, so a entrada "langue", se diferencia entre linguas primitivas e linguas de cultura, se canta as excelencias dun idioma capaz de se facer internacional e se propón o francés como lingua da liberdade e da Revolución, en contraste cos patois. O propio Rousseau, no seu Essai sur l'origine des langues, de 1756, ao tratar dos primeiros seres humanos, distinguía entre linguas do norte -ásperas, sonoras, claras- e linguas do sur-elocuentes, vivaces, escuras-; e canto ás linguas modernas, cualifica as do norte (francés, inglés e alemán) de frías e feitas polo razoamento e a cooperación, en canto as do sur serían aptas para falar dos misterios sagrados, promulgar leis e guiar as multitudes.

Nos séculos XVIII e XIX proliferan as defensas apoloxéticas das linguas, mais con diferenzas entre a apoloxía das linguas consideradas fortes e a das tomadas por febles ou fracas, a primeira con clara tendencia cara ao imperialismo lingüístico, como

2 Véxase "As vellas pegadas da etnolatría" en Tuson (1990: 33-51), de onde sintetizamos algunhas referencias. Precisamente na discriminación social da lingua oral e popular face á lingua normativa (“correcta") basea Bagno (2003, 2005) o seu combate contra os preconceptos lingüísticos no Brasil. 
demostra a seguinte cita de Lomonosov (século XVIII): "Soberana de moitas linguas, a lingua de Rusia é grande diante de todas as linguas de Europa non só pola extensión dos lugares onde reina como, máis aínda, polas súas dimensións e opulencia”3. En troca, algúns apoloxetas de linguas febles aceptan a reclusión destas no ámbito familiar e na poesía, como exemplifica o seguinte texto de Tomàs Forteza, de 1886: "Impere en boa hora no alcázar da Ciencia a lingua castelá, sen que por iso negue un sitial á súa irmá desfavorecida; porén, as portas sagradas do templo da Poesía están francamente abertas para as dúas" (en Tuson, 1990: 49). No entanto, tamén se producen reaccións defensivas desmesuradas das linguas fracas, de que é unha boa mostra a "Introdución" de Curros (1886) a Aires d'a miña terra. Dános máis exemplos Moreno Cabrera (2006a: 83-85), quen afirma que todos temos dereito a cantarmos as excelencias das nosas linguas "porque nunca nos faltará razón”, mais o que non está obxectivamente xustificado é facérmolo a custa ou en detrimento doutras linguas.

Non faltan tampouco declaracións sobre a igualdade das linguas, na procura de pór cada un a súa á altura das demais, e sobre a natural defensa da lingua propia, como fai por exemplo Curros na segunda parte da súa "Introdución" antecitada e máis dun século antes Carles Ros en 1752 na obra Cualidades y blasones de la lengua valenciana. Uns poucos anos atrás, en 1726, o Padre Feijóo publicaba o "Paralelo de las lenguas castellana y francesa" como Discurso XV do seu Theatro Crítico Universal, seguido dun "Corolario" en que sostén a primacía do galego sobre o portugués, o que lle vale unha réplica irada de Ernesto Frayer, pseudónimo do diplomata portugués Martinho de Mendoça de Pina e de Proença Homem, que un ano máis tarde publica o Discurso Philologico Crítico sobre el Corolario del Discurso $X V$..., onde proclama o superior estatuto do portugués a respecto do castelán e termina cunha descualificación contundente do galego. No mesmo século XVIII o Padre Sarmiento polemiza retrospectivamente con Duarte Nunes de Leão, que en 1606 publicara a obra Origem da lingua portuguesa, onde consideraba a lingua galega inferior á de Portugal e negaba a existencia mesma do reino da Galiza ${ }^{4}$. As polémicas, pois, entre apoloxetas dunhas e doutras linguas proliferan nos séculos XVIII e XIX, inzadas de preconceptos lingüísticos, e nelas tamén está presente o galego. E de certo que unhas e outros continúan a ter presenza no XX, nalgún caso de forma ben extremada e depreciativa cara ás linguas minorizadas: "Y siniestros son todos esos movimientos y esfuerzos, ahora frecuentes, por recluír a las gentes en las lenguas minoritarias, por alentar de un modo u otro el espíritu de campanario, por querer transmutar la babelización de maldición bíblica en bendición cultural"

3 Cita aducida por Seriot (1984) e traducida en Tuson (1990: 48); tamén reproducida, con variantes de tradución, en Moreno Cabrera (2006a: 85); este autor infórmanos igualmente de que o barón de Ryckholt publicou en 1868 un libro co elocuente título O flamenco, lingua primeira, nai de todas as linguas (Moreno Cabrera 2006a: 83).

4 Estas e outras polémicas entre galegos e portugueses poden verse máis por extenso en Freixeiro (2006: 39-57). 
(Salvador 1987: 66). Aínda na actualidade sobreviven os preconceptos lingüísticos, se callar en ocasións máis sutilmente expresados ou disfarzados. Unha clara mostra constitúea o "Manifiesto por la lengua común"5 - o español, claro está-, que no ano 2008 andaba a apañar sinaturas a prol dun idioma pretensamente ameazado que é o único que todos os cidadáns e cidadás do Estado teñen a obriga constitucional de coñeceren e que é tamén idioma oficial noutros moitos países do mundo. Outro exemplo dánolo algunha publicación dunha fundación ligado ao Partido Popular, que aínda a inicios de 2009 arremetía dunha maneira totalmente preconceptuosa contra a lingua galega. O máis preocupante é que, alén de ser máis unha mostra da sobrevivencia dos preconceptos lingüísticos, os principios ideolóxico-lingüísticos que moven tal fundación acharon amplo eco na propia Galiza e actualmente están a inspirar a política lingüística do novo Goberno galego.

Por tanto, existiron e continúan a existir preconceptos lingüísticos no Estado español, na Galiza e no mundo, que en xeral son utilizados contra as linguas minorizadas e que desde o noso ámbito xeopolítico presentan unha clara visión eurocéntrica (Moure 2005, 2006). Estes preconceptos son moi variados e atéstanse so formulacións diversas, aínda que teñen un fondo común que non é outro máis que o desprezo pola diferenza e o afán de asimilación imperialista. As tentativas de clasificación existentes presentan en xeral moitos puntos en común, independentemente do ámbito para o que se formularen. Nun espazo xeolingüístico concreto como é o do Brasil, Marcos Bagno (2003: 13-72) sinala os seguintes "mitos" do preconcepto lingüístico: "A língua portuguesa falada no Brasil apresenta uma unidade surpreendente"; "Brasileiro não sabe português / Só em Portugal se fala bem português"; "Português é muito difícil"; "As pessoas sem instrução falam tudo errado"; "O lugar onde melhor se fala português no Brasil é o Maranhão"; "O certo é falar assim porque se escreve assim"; "É preciso saber gramática para falar e escrever bem"; e "O domínio da norma culta é um instrumento de ascensão social". Nestes mitos subxacen varios preconceptos lingüísticos baseados nas peculiares características sociolingüísticas do Brasil, onde, unha vez que case se conseguiu exterminar as linguas indíxenas, a discriminación por motivo do idioma utilizado afecta as distintas variedades ou maneiras de falar a lingua oficial; naturalmente, o modelo do ben falar estabeléceno as clases superiores e as inferiores son vítimas, alén dunha discriminación socioeconómica, doutra tamén lingüística ${ }^{6}$.

Moreno Cabrera (2006a: 237-265), por súa vez, recolle cen “mitos, prejuicios y tópicos" sobre as linguas que tratan arredor dos seguintes temas: a orixe das linguas

5 Sobre a polisemia do termo ‘común’ aplicado ao español véxase López García (2007).

6 O propio Bagno (2001: 15) sostén con rotundidade que o preconcepto lingüístico manifesta nas súas diversas formas e nas diferentes faces "a ideologia cristalizada há séculos na Gramática Tradicional (GT) e materializada, por assim dizer, no gênero literário conhecido como gramática normativa (GN)". 
e da linguaxe humana; o número de falantes das linguas; estado, nación e lingua estándar; facilidade e dificultade das linguas; variedades lingüísticas e prestixio social; a lingua materna; idioma e léxico; lingua escrita e cambio lingüístico; filólogos, tradutores, lingüistas e outras especies intelectuais. Moitos destes temas aparecen tamén nos criterios de clasificación recollidos por Tuson (1990), baseados xeralmente na contraposición entre unhas linguas que se poderían cualificar como boas, importantes ou adecuadas para a vida actual, e outras que non terían estas propiedades e que, por tanto, habería que considerar como más, irrelevantes ou non aptas para os tempos que corren ${ }^{7}$. Un primeiro grupo estabelecido por Tuson (1990: 56-69) é o dos preconceptos inocentes ou populares, que permiten estabelecer de forma maniquea o seguinte agrupamento de linguas: sinxelas vs. complicadas -para os falantes nativos non hai linguas complicadas, de modo que as crianzas chinesas non tardan máis en falaren do que as francesas-, suaves vs. ásperas -serán en todo o caso as persoas as que falen de forma máis suave, máis enérxica ou áspera- e linguas con moitos vs. pouco falantes -o número de falantes de cada lingua poden contarse de varias maneiras e case sempre de forma interesada ${ }^{8}$. O segundo grupo que estabelece Tuson (1990: 73-91) é o dos prexuízos culturais, segundo os que se pretende falar de linguas de cultura vs. primitivas -algunhas destas presentan unha complexidade estrutural superior ás anteriores e finezas extraordinarias ${ }^{9}-$, linguas literarias vs. non literarias -a práctica totalidade das linguas foron faladas e non escritas durante toda ou a maior parte da súa existencia ${ }^{10}$ - e linguas vs. dialectos -porén a lingua estándar provén dun dialecto magnificado pola administración e polo poder ${ }^{11}$. Por último, fala Tuson (1990: 95-111) de preconceptos xeopolíticos, que propician a discriminación entre linguas maioritarias vs. minoritarias -no canto de descualificar directamente as linguas periféricas ou 'rexionais' fálase das vantaxes

7 Segundo máis adiante se verá, os preconceptos pretenden levar o galego para este segundo grupo, onde polo común se achan as linguas minorizadas e non oficiais dos estados.

8 Confróntense os datos de diferentes estudos estatísticos en Tuson (1990: 64-66); para os falantes das linguas de Europa véxase Costas (2002). Sobre a subxectividade na interpretación do número de falantes véxase Salvador (1987: 56-66). Por outra parte, no mundo hai 208 linguas con máis de un millón de falantes e a maioría sonnos descoñecidas para os europeos (Moure 2005: 137).

9 O cheyenne, por exemplo, ten dúas terceiras persoas pronominais que permiten especificacións do referente que non realizan as linguas romances, o esquimó ten unha palabra para designar a neve que cae e outra para a neve caída, a complexidade verbal do navaho é moi superior á do latín (Moure 2006: 106-107) etc.

10 Véxanse os cadros de emerxencia das linguas nacionais europeas en Baggioni (2004: 67-69), onde se indica a data de aparición dos textos escritos, que en ocasións se sitúa no século XIX.

11 O propio Lapesa (1962: 125), no seu afán por enxalzar o español, admite a súa procedencia dialectal: "El dialecto castellano evoluciona con más rapidez que los otros y, según veremos, se muestra distinto de todos, con poderosa individualidad. Castilla, levantisca y ambiciosa en su política, revolucionaria en el derecho, heroica en su epopeya, fue la región más innovadora en el lenguaje. Y así como su prodigiosa vitalidad la destinaba a ser el eje de las empresas nacionales, su dialecto había de erigirse en lengua de toda la comunidad hispana". 
da lingua de todos-, linguas con estado vs. linguas sen estado -a identificación entre lingua e estado é totalmente contraria á realidade, segundo demostra o caso de Europa (Costas 2002, Baggioni 2004) ${ }^{12}$ - e linguas de comunicación vs. linguas locais -todas as linguas son de comunicación, sen excepcións, embora unhas permitan comunicarnos con máis xente do que outras.

En conclusión, en canto nos gabamos de pertencermos a sociedades avanzadas, moitas linguas van morrendo, e con elas moitas culturas, mediante a propagación de preconceptos lingüísticos e a promoción das desigualdades entre os países, de modo que a sorte dos idiomas vai unida á historia dos pobos dominadores e dominados, aínda que agora o poder adopte formas máis pretensamente civilizadoras do que colonizadoras, mais sempre coa intención de ir acabando coas diferenzas, tamén lingüísticas. No fondo, non se nos convida tanto a aprendermos unha segunda ou terceira lingua que puider abrirnos novos camiños como a renunciarmos á propia.

\section{Os preconceptos a respecto do galego}

O que acontece no marco mundial canto a discriminación e intolerancia lingüística mediante a extensión dos preconceptos, está tamén a acontecer no Estado español e na Galiza, onde o galego non consegue liberarse duns preconceptos historicamente alimentados e propagados por un poder central e centralista que, no fondo, e alén de declaracións retóricas, continúa á procura do uniformismo político, cultural e lingüístico. Como lingua minorizada que foi no seu propio territorio durante quiñentos anos, o galego é vítima aínda hoxe dos preconceptos acumulados nese longo período e inclusive sofre outros novos como consecuencia das transformacións que experimentou o contexto sociolingüístico galego e as circunstancias sociopolíticas no Estado, en Europa e no mundo. O proceso de globalización ou mundialización actual trae novas formas de dominio sobre as nacións e as culturas periféricas e xera tamén novos preconceptos sobre as linguas minorizadas.

\subsection{Xénese e evolución dos preconceptos lingüísticos na Galiza}

Parece evidente que a maior parte dos preconceptos a respecto do galego se xeraron a partir de finais da Idade Media, isto é, desde o momento en que se perdeu a normalidade lingüística por imposición dunha lingua allea, o castelán, como lingua do poder. Os preconceptos que anteriormente puidesen existir serían máis ou menos

12 A situación lingüística no mundo é consecuencia directa de relacións de dominio, conquista e colonización duns pobos sobre outros, como testemuña, por exemplo, a proxección internacional do francés antes e do inglés agora. Segundo afirma Junyent (1986), son os falantes e, en definitiva, os pobos os que son fortes ou febles, grandes ou pequenos, e non precisamente pola súa lingua, mais en xeral pola súa capacidade de agresión. 
os mesmos que afectaban as linguas en xeral. Coa subordinación do galego ao castelán, nos séculos escuros xa comezan a aparecer os preconceptos, a acompañaren o lento proceso de substitución lingüística e de asimilación político-cultural que pode conducir á morte da lingua. David Crystal (2003: 120-121), ao tratar sobre a morte das linguas, sinala precisamente a asimilación cultural como factor decisivo para a substitución lingüística e afirma que cando unha cultura asimila outra a orde de eventos que afecta a lingua en perigo parece ser a mesma en toda a parte: primeiro, unha inmensa presión de orde política, social ou económica para que as persoas falen a lingua dominante; como resultado, en segundo lugar, un período de bilingüismo emerxente en que as persoas se van facendo cada vez máis competentes na nova lingua sen esqueceren a orixinal, aínda que co tempo esta comeza a declinar; e, en terceiro lugar, a xeración máis nova vai facéndose máis competente na nova lingua e identificándose máis con ela, de modo que a orixinal comeza a perder prestixio, xorden actitudes negativas dos falantes cara a ela e aparecen sentimentos de vergoña por a falaren ou por seren identificados con ela, de modo que progresivamente se vai convertendo en lingua residual da xente maior que a usa no reduto doméstico como dialecto familiar. Neste proceso descrito por Crystal e aplicábel ao galego cos seus ritmos propios, as actitudes e os preconceptos desempeñan, como se ve, un papel importante e conducen á morte das linguas. De aí a importancia da súa superación para a sobrevivencia do galego neste caso.

Fica claro que o discurso socialmente dominante na Galiza e que contén os preconceptos lingüísticos en contra do idioma propio se foi conformando ao longo dos séculos, nun lento proceso de imposición e substitución lingüística que dura centos de anos. En consecuencia, mudar eses preconceptos tan longamente adquiridos implica grandes dificultades e tamén moito tempo, pois non se pode destecer nuns días o que se teceu en séculos. A mellor estratexia para combater os preconceptos será, por tanto, cuestionar ese discurso estabelecido e intentar modificalo mediante o coñecemento das causas en que asenta. Moitas destas serán de carácter histórico e nelas haberá que profundar; outras obedecen a factores máis achegados á actualidade. Poderase falar, así, de vellos preconceptos, como a vinculación do galego ao mundo rural e ao atraso, tamén aos ámbitos informais, e de novos preconceptos, aparecidos na transición democrática e no inicio do proceso de normalización, como a asociación do galego a un determinado perfil político ou os preconceptos da súa imposición.

Nas páxinas sucesivas iranse analizando algúns destes preconceptos, vellos e novos, mesturados con tópicos que socialmente veñen funcionando en contra do galego. Tamén se verá como uns preconceptos van asociados a outros, a se demostrar desta forma que existe unha causa fundamental de fondo que non pode ser outra máis que o proceso de colonización política, cultural e lingüística levado a cabo no país desde finais da Idade Media. A ideoloxía do poder alleo imposto na Galiza desde entón foi 
xerando actitudes de desprezo do propio e perda da autoestima, creando estereótipos (os galegofalantes son ignorantes, brutos etc.) e preconceptos (o galego non serve para o progreso etc.) que inclusive deron orixe ao complexo de inferioridade. $\mathrm{Na}$ actualidade parecía térense reducido os preconceptos sobre o galego entre a xente nova, embora isto non se traducise nun aumento do uso desta lingua nas novas xeracións, mais nos estudos elaborados ao respecto (González 2003, Iglesias 2003 e 2007) aínda se constata unha presenza importante de preconceptos nesa faixa etárea, de modo que a idade non semella unha variábel tan destacada ao falarmos deles. $\mathrm{Na}$ realidade, a mocidade o que fai é reproducir os preconceptos que aprendeu da xente maior e que circulan a través do discurso socialmente operante. Por iso é preciso xerar un contradiscurso capaz de anular os efectos daniños do histórica e socialmente dominante se se quixer combater con eficacia os preconceptos lingüísticos ${ }^{13}$.

\subsection{Tentativa de agrupamento e clasificación dos preconceptos sobre o galego}

Non cabe dúbida de que un período tan longo de subordinación e desprestixio como o que sufriu o galego tiña de provocar o aparecemento de moitos e variados preconceptos, algúns coincidentes cos que costuman afectar todas as linguas en situación similar de minorización e outros específicos das peculares circunstancias que rodearon a historia e a situación actual da lingua galega. Deixando de lado unha primeira clasificación, xa aludida, entre novos e vellos preconceptos, que de todas as formas será tida en conta no sucesivo, podemos agrupar os preconceptos que afectan a lingua galega arredor de seis grandes eixos temáticos: preconceptos relacionados coa suposta falta de utilidade do galego, aqueles que o asocian coa pobreza e co atraso, a súa consideración como sinal de descortesía ou má educación, os preconceptos relacionados coa pretensa imposición do galego, a caracterización pexorativa deste e a (in)competencia dos seus falantes e, por último, o galego como marca ideolóxica ou profesional. Como se dixo, existe unha estreita relación entre todos eles e uns levan séculos axindo en canto outros son de recente creación.

\subsubsection{Preconceptos relacionados coa suposta falta de utilidade do galego}

É este un dos grupos de preconceptos máis daniños, pois en xeral aquilo que non se sente como útil acaba sendo rexeitado e abandonado. Se o galego non fixer ver a súa utilidade para a sociedade, esta viraralle as costas. Arredor deste grande preconcepto agrúpanse outros directamente relacionados con el; ou, dito con outras palabras, este preconcepto preséntasenos so diferentes formulacións. Unha é a de que galego

13 Unha excelente e intelixente aproximación ao combate dos preconceptos lingüísticos entre a xente nova, cun enfoque á vez lúdico e didáctico, áchase en Núñez Singala (2009) e tamén en Sende (2007). 
isola a Galiza do exterior, se callar o preconcepto máis estendido, e tamén un dos máis vellos; baséase en que a lingua propia couta a proxección da Galiza fóra das súas fronteiras e detrás del está a idea de que co galego non se pode ir a ningures -por tanto, non é útil. A mellor proba para a negación deste tópico áchase na propia historia do idioma: durante a Idade Media o galego foi a única lingua da Galiza, falada por todas as clases sociais e empregada na escrita cando os romances substituíron o latín neste ámbito. Lonxe de iso supor o illamento da Galiza, esta tivo a maior proxección exterior da súa historia e a ela acudían en peregrinaxe xentes de toda a Europa. Alén diso, débese ter en conta tamén a real posibilidade que a lingua galega ofrece de comunicación con aproximadamente 230 millóns de habitantes dos diferentes continentes que son de expresión galego-portuguesa. O galego é unha das linguas máis estendidas polo mundo, pois, nado na Gallaecia, de onde tamén xurdiu Portugal, foi levado por este aos diferentes continentes. Por iso se pode afirmar que en Portugal, no Brasil e noutros territorios se fala galego, aínda que agora lle dean outro nome, como afirma a escritora María Xosé Queizán: “Aquí na Galiza debemos superar a mentalidade colonizada e adoptar a posición forte. Proclamar que o galego é a lingua de millóns de persoas en varios continentes, con cultura e literatura importantísimas e unirnos a elas, falando como falamos"14. O propio Castelao (1961: 346) xa tiña estas ideas ben claras bastantes anos antes ao afirmar que "todo canto se veu chamando 'galaico-portugués' é realmente e unicamente 'galego"'. Por iso un informe do Consello da Cultura Galega sobre a análise e as perspectivas da política lingüística na Galiza no período 1980-2000 (Monteagudo / Bouzada 2002: 200), ao dar conta da opinión das persoas expertas mediante a técnica DELPHI, afirma que "son maioritarias as opinións que sinalan que os responsábeis lingüísticos deberan apostar de forma máis decidida por achegar o galego á área luso-brasileira". O galego, pois, lonxe de isolar a Galiza do exterior, abre as portas ao mundo e móstrase neste aspecto como unha lingua extensa e útil, segundo a cualificou Castelao.

Outra derivación do prexuízo da falta de utilidade do galego é tópico da lingua universal, cuxos defensores parecen ver nas diversas linguas un obstáculo para a comunicación, cando na realidade todas son válidas para tal fin. Mais unha lingua tamén é, alén diso, a síntese da personalidade histórica e colectiva dun pobo. O mesmo Curros Henríquez se sentiu seducido por esta idea do idioma universal, mais esta crenza na necesidade dunha lingua universal que substitúa todas as demais bate nel, como en calquera persoa consciente e orgullosa do herdo dos seus antepasados, co amor que sente pola súa propia, e por iso acaba por afirmar que esa lingua universal será o galego. E continúa a composición a facer unha apaixonada defensa da lingua galega ("fala de miña nai", "fala de meus avos", "idioma en que garulan os paxaros", "en que falan os ánxeles ós nenos") e reiterando que esta non pode desaparecer:

14 Artigo publicado n'A Nosa Terra, 1-5-97. 
“non, ti non morrerás", "ti non podes morrer" etc. (Curros 1886: 3-6) ${ }^{15}$. Un idioma universal, lonxe de enriquecer o xénero humano, empobreceríao culturalmente e deshumanizaríao. Ben o explica tamén Castelao (1961: 43): "Un can de Turquía ouvea igual que un can de Dinamarca; un cabalo das Pampas arxentinas rincha igoal que un cabalo da Bretaña. ¿E sabedes por que? Porque os probes animaes aínda están no idioma universal...”. A enriquecedora variedade lingüístico-cultural da humanidade en nada se contradí coa existencia en cada momento dunha lingua que asuma a función de lingua internacional para as relacións comerciais ou doutro tipo; tal lingua antes foi o latín, hoxe parece cada vez máis ser o inglés e mañá pode ser outra, sempre en función do poder político e económico do país ou países en que se falar. Non se nega, por tanto, o valor do inglés ou doutras grandes linguas estatais para as relacións internacionais. Porén, a súa indubitábel importancia non debe contraporse á defensa da diversidade lingüística nin debe servir como escusa para negar o papel doutras linguas, porque entón estase a lexitimar o imperialismo lingüístico, unha das principais causas de morte das linguas. O dominio dunha lingua a expensas doutras como consecuencia da conquista militar, política e económica foi cualificado por Calvet (1993) como 'colonialismo lingüístico' e 'glotofaxia', a se basear na experiencia do imperialismo racista de Occidente. Para Moreno Cabrera (2008: 144-145) a ideoloxía nacionalista colonial ten como desenvolvemento lóxico a 'ideoloxía nacionalista imperialista', que no plano lingüístico acabou por dexenerar "de modo casi inevitable en una especie de megalomanía, de delirium tremens, que abarca en sus ensoñaciones imperiales" a totalidade da humanidade, como aconteceu coa "construcción del mito del español como idioma universal". Phillipson (1992: 47) fala directamente do imperialismo lingüístico do inglés (English linguistic imperialism), que se produce cando o dominio desta lingua é afirmado e mantido polo estabelecemento e reconstitución continuada de desigualdades estruturais e culturais entre ela e outras linguas. Considérao un subtipo do 'lingüicidio' (linguicism), que define como ideoloxías, estruturas e prácticas que se usan para lexitimar, realizar e reproducir unha desigual distribución de poder e recursos entre grupos definidos lingüisticamente. En conclusión, o tópico da lingua universal conduce ao imperialismo lingüístico e este provoca a morte de moitas das linguas do mundo. No caso do galego é o imperialismo lingüístico español ou 'españolismo lingüístico' (Rodríguez Alonso 2004), cuxo discurso leva moitos anos a circular, o que ameaza o seu futuro.

Por outra parte, tamén se estende o preconcepto de o galego ser unha lingua subsidiada. Suxírese que, por non ser útil nin economicamente rendíbel, vai manténdose, sobre todo no ámbito cultural escrito, a base de subsidios, pois o Goberno galego e outros organismos públicos subvencionan edicións de libros en galego e actos culturais

15 Xa deixara dito alá polo século XVI Cristóbal de Villalón a se referir ao castelán: "Harto enemigo es de si quien estima más la lengua del otro que la suya propia” (en Lapesa 1962: 204) 
vehiculizados a través deste idioma e sobre a cultura galega, para alén de pagaren o profesorado que imparte cursos desta lingua. Porén, isto é algo normal que se realiza en todos os países cunha lingua propia e normalizada; o Goberno español tamén subsidia a cultura de expresión en lingua castelá. Inclusive a Xunta da Galiza contribúe economicamente para financiar a Real Academia Española e o Instituto Cervantes é financiado igualmente con contributo dos galegos ${ }^{16}$.

Existe, por último, o preconcepto de o galego non xerar riqueza. Sen lle negar os valores que puider ter, porén afírmase que non contribúe para a produción de riqueza e por tanto non é un factor de progreso económico. Na actualidade case todo se mide con criterios de rendibilidade material, mais tamén nestes parámetros a lingua propia desempeña un importante papel. Nettle e Romaine (2000: 153) falan de 'neglixencia benigna' como expresión nun principio utilizada para designar unha política de non intervención da metrópole en contextos coloniais e que define as linguas como entidades en mudanza constante e de traxectoria imprevisíbel, que morren porque os seus falantes tomaron consciencia da súa desactualización e optaron por outras con mellores oportunidades económicas, sociais e laborais. Trataríase así dunha mudanza cualitativa cuxa 'única' desvantaxe sería a perda dunha herdanza cultural específica, isto é, un efecto secundario inevitábel do progreso. Máis un paso e xa nos situamos na ideoloxía do imperialismo ou nacionalismo lingüístico español (Moreno Cabrera 2008: 106-109) de que as persoas, neste caso galegas, renuncian voluntariamente á súa lingua propia porque o castelán lles resulta máis atractivo e mellora as súas condicións de vida (Lodares 2000: 197). No entanto, a experiencia histórica demostra o contrario: eis o caso de Inglaterra, co inglés convertido en lingua subalterna do francés durante uns trescentos anos -tantos como os séculos escuros na Galiza-e hoxe unha das súas principais fontes de riqueza. O incuestionábel valor de identidade que a lingua galega posúe deberá traducirse necesariamente tamén en valor económico, pois as potencialidades que neste sentido ten unha lingua asociada a unha cultura propia e milenaria son inmensas. Inclusive no sector turístico, que as veces se invoca en sentido negativo para o uso da lingua propia, esta é máis un atractivo, pois as persoas viaxan para coñeceren algo novo e distinto e moitas son atraídas polo existencia dunha cultura claramente diferenciada. Como principal sinal de identificación colectiva dun pobo, a lingua propia é tamén o seu primeiro potencial de desenvolvemento económico e arredor dela poden moverse diversas actividades económicas de importancia. Pénsese no caso galego en sectores como o editorial, o audiovisual, o das novas tecnoloxías, o turístico, o ensino etc., algúns aínda moi deficientemente explorados. Se tantas persoas viven, dunha forma ou

16 O Instituto Cervantes non está dedicado precisamente ao estudo da vida e da obra do grande escritor (Moreno Cabrera 2008: 146), mais si a estender o dominio do español no mundo como representante institucional "de una ideología nacionalista castellanocéntrica dirigida desde Madrid y asumida en parte en el mundo hispánico, claramente evidente también en la RAE [Real Academia Española]" (Moreno Cabrera 2008: 158). 
doutra, do inglés, francés, italiano ou español, será porque a súa lingua normalizada é rendíbel para eses países. A normalización do galego tamén será sen dúbida un bo negocio - un bo investimento- para a Galiza.

\subsubsection{Preconceptos que asocian o galego coa pobreza e co atraso}

Estes xa vellos preconceptos gardan relación cos anteriores, pois se unha lingua é cualificada de atrasada ou propia de pobres tamén se está a suxerir a súa falta de utilidade nunha sociedade que pretende ser rica e avanzada. Son varias as formulacións en que tales preconceptos transparecen. A primeira é a de ser o galego unha lingua rural, pois a asociación do galego coa pobreza (Garcia Negro 1993: 6163) tamén está en relación coa súa identificación co mundo rural, símbolo tradicional do atraso face ao progreso do mundo urbano. Así, galego e mundo tradicional labrego e mariñeiro, ou galego e aldea -que viría sendo o mesmo que dicir galego e miseria, atraso ou pobreza-, son conceptos que no imaxinario colectivo funcionan asociados. En troca, prodúcese a asociación entre castelán e progreso, pois tradicionalmente todo o moderno e innovador, todo aquilo que supuña un avanzo ou era máis propio da xente da cidade e das persoas instruídas, ligábase ao castelán e mesmo no subconsciente das persoas galegofalantes se producía un automático rexeitamento do galego neses ámbitos. Este preconcepto con base histórica, pois o galego foise vendo cada vez máis recluído no mundo rural, supón unha seria ameaza para o seu futuro por se tratar dun mundo en transo de desaparecemento. Así, Roca (1997: 465) considera que a Galiza histórica está morta ou a punto de morrer, e con ela esa Galiza campesiña tradicionalmente galegofalante; e que a acelerada desintegración interna do galego como resultado das interferencias da lingua dominante, propia das linguas moribundas, e o seu esgotamento externo tamén acelerado como consecuencia dunha constante perda de falantes, anuncian a súa morte inminente ${ }^{17}$. Por iso é tan importante que o galego non apenas manteña, mais tamén incremente a súa presenza no mundo urbano, feito que hoxe está lonxe de acontecer (Rei-Doval 2007, González 2008). Con todo, convén reafirmar que o galego, como todas as linguas, é tan apto para o mundo rural como para o urbano.

Outro preconcepto deste grupo é o de o galego non ser lingua válida para a escrita. Posúe un claro fundamento histórico, pois durante os séculos escuros practicamente deixou de ser lingua escrita e aínda no XIX Pintos (1853: 37) afirmaba que o galego non se usaba Para leis, nin escrituras, / Nas oficinas, nin tempros, / Nin poñen declaracios,/ Nin estenden testamentos. Por volta de 1925 Dieste (1981: 24) recriminaba os mozos galegos por pretenderen escribir as cartas familiares cando estaban facendo o servizo militar nun español que non sabían: "Isas cartas

17 A fórmula que o autor utiliza é: 'Accelerated internal desintegration + accelerated external depletion $=$ imminent death’ (Roca 1997: 465). 
nun castelán mal escrito e misturado que mandades cando estades fora, fan rir, podedes crér que fan rir". Isto pon en evidencia a imposción do español como lingua da escrita a quen era monolingüe en galego e a profundidade da asimilación lingüística producida na Galiza. Inclusive se foi máis lonxe que nos procesos de colonización ultramarina, onde ás veces se contemplaba a aprendizaxe da escritura na lingua propia como paso necesario para a instalación na lingua dominante, segundo aconteceu coa imposición do castelán nalgunhas populacións americanas, supostamente coa intención de liberar as persoas primitivas do atraso para as integrar no progreso: "Es necesario que las cosas sean así, para mejora de gentes que viven en estado de miseria y para el desarrollo equilibrado de naciones en marcha, que no pueden caminar con el lastre de cientos de miles de personas ajenas a la obra que la colectividad ha emprendido" (Alvar 1971). Porén, cabe preguntármonos se eses miles de persoas foron consultadas sobre a súa vontade de integración. No caso da Galiza, o castelán foi imposto como lingua da escrita por vía dos feitos desde finais da Idade Media por parte dun poder de procedencia foránea e a lingua galega só entrou na escola hai unhas poucas décadas de forma tímida, sen chegar a se converter con carácter xeral na lingua da lecto-escritura. Debido ao presitixio que posúe a escrita nas sociedades actuais, faise precisa e imprescindíbel a presenza da lingua galega nese ámbito para a súa normalización. Os avanzos dos últimos anos, con seren importantes, non conseguiron superar a esfera da Administración pública, onde aínda existen lacunas importantes.

Persiste aínda, embora talvez mitigada con relación a tempos pasados, a asociación do galego á pobreza e á ignorancia, vello preconcepto derivado do feito de as clases altas e instruídas, incluídas as autoridades eclesiásticas, iren desertando da súa lingua para adoptaren a do poder foráneo estabelecido desde finais do período medieval. Porén, a deserción non foi unánime nin instantánea, de modo que até o século XIX non se pode dar por consolidada definitivamente. Mais o lento proceso foi afectando o prestixio do galego e a deserción estendeuse ás clases medias, que procuraban o ascenso social mediante o uso do español. E mesmo chegou a penetrar nas clases populares, que nalgún caso tentan abandonar a súa lingua na procura dunha mellora no seu status social. En moitos casos a xente foxe do galego para realmente fuxir dun pasado cheo de privacións e da pobreza e da ignorancia con que ese idioma se veu asociando durante séculos.

En relación directa con este preconcepto está o de considerar o estudo do galego ou en galego como unha perda de tempo e un atraso. Chega a dicirse que veu a supor un inconveniente para as crianzas e para todo o país, pois esas horas poderían empregarse en aprenderen cousas máis proveitosas, que supostamente ían redundar nuns estudantes máis preparados e por tanto nunha Galiza máis próspera. Subxace neste argumento a idea de que o galego é un atranco para o progreso. Ora, de sermos coherentes con esta argumentación, teriamos de afirmar que a Galiza estivo nos 
últimos séculos na vangarda do progreso, pois desde hai centos de anos o galego permaneceu totalmente afastado do sistema educativo e ningún neno ou nena galego foi obrigado a perder un só segundo en estudar a súa propia lingua. Mais a historia ensina que durante os séculos escuros, o século XIX e parte do XX, xusto cando o galego estivo afastado das aulas, a Galiza viviu sumida maioritariamente na miseria e na ignorancia, achando como única saída o drama da emigración. A expulsión do galego do ensino ben pode ser cualificada de 'xenocidio lingüístico', de acordo con Skutnabb-Kangas (2000), que opina que a maioría dos sistemas de educación do mundo cometen un xenocidio lingüístico e cultural ao prohibiren o uso da lingua minorizada na actividade diaria nas aulas. Na Galiza tal prohibición na práctica durou centos de anos e, asumido o preconcepto da incapacitación do galego para este ámbito, cando se intenta reparar xorde o novo preconcepto da imposición, a que logo se aludirá.

\subsubsection{O uso do galego como sinal de descortesía ou má educación}

Outro grupo de preconceptos utilizados como argumento para frear calquera intento de normalización lingüística é o de considerar o emprego do galego como un sinal de descortesía ou de falta de educación en determinados contextos. Así, esténdese a idea de que o emprego do galego con persoas descoñecidas é unha desconsideración cara a elas, pois podería ser que o non entendesen ou que non quixesen que se lles falase nesa lingua. De asumir iso, estaríase a aceptar para o español a condición de lingua superior e colonizadora, reservando para o galego un papel totalmente subordinado como lingua inferior condenada á progresiva desaparición. O natural semella ser o uso do idioma do país como primeira opción na comunicación con todas as persoas e, en todo o caso, recorrer logo a outras linguas -nomeadamente o español- cando se puxeren de manifesto problemas de comprensión. Inclusive se podería inverter o argumento e presupor que non utilizar a lingua propia do país cunha persoa descoñecida sería considerar esta menos capaz e preparada e, por tanto, podería estar sendo tratada en certo modo descortesmente.

Como ampliación do preconcepto anterior, tamén circula o discurso da necesidade de renunciar ao uso do galego por respecto ás persoas foráneas. Preténdese dicir que non se debe falar galego en público ou mesmo en determinados contextos do ámbito privado por consideración con aquelas persoas que puideren ser de fóra da Galiza, como se o seu uso implicase descortesía ou fose unha mostra de má educación. De isto ser así, de o respecto ás persoas implicar a renuncia a empregar unha lingua publicamente, deberase renunciar a calquera proxecto de futuro para ela, pois non será posíbel emprender nunca ningunha acción normalizadora efectiva perante esa posibilidade cada vez máis real no mundo actual. As persoas que proceden de fóra, sempre merecedoras de todo o respecto, deben saber que veñen a unha comunidade con lingua propia e, por conseguinte, elas mesmas serán-ou deberán ser e en moitos 
casos xa o son-as primeiras en respectaren esa realidade histórica e non pretenderen que todo un pobo deixe de falar na lingua que falou durante séculos por culpa delas. Aliás, as persoas que veñen á Galiza non poden ter máis dereitos dos que teñen as galegas cando saen fóra, cousa que infelizmente aconteceu -e aínda en parte está a acontecer- con moita frecuencia por culpa da endémica emigración motivada por factores económicos. Porén, na realidade o problema non está tanto aí, pois as persoas procedentes de calquera comunidade española, de o desexaren, pasan a ser galegas de pleno dereito e poden integrarse na sociedade e exercitaren os seus dereitos cívicos, incluídos os lingüísticos, para o que con seguranza acharán bastantes máis facilidades que os galegofalantes. A proximidade entre galego e castelán facilita tamén moito a incorporación ao galego daquelas persoas que o desexaren. Neste sentido, tórnase especialmente interesante a proposta de sesquilingüismo cooperativo -a capacidade de entender unha lingua sen necesidade de a falar, isto é, monolingüismo produtivo acompañado por bilingüismo ou plurilingüismo receptivo- do profesor Moreno Cabrera (2006b: 63), que pode contribuír para preservar a pluralidade lingüística dentro do Estado español, pois se no sistema educativo se incluíse a adquisición de competencias pasivas nas diferentes linguas, ninguén se vería forzado a utilizar outra distinta da súa; e na Galiza sen dúbida eliminaría obstáculos ou escusas para a plena normalización da lingua galega, pois ningunha persoa podería aducir o seu descoñecemento nin considerar descortés que lle falen nunha ou noutra. Tamén se pregunta López García-Molins (2008: 78) que se pode facer para que España sexa realmente un Estado plurilingüe e, sen citar o termo sesquilingüismo, fai unha proposta no mesmo sentido na procura do 'plurilingüismo equitativo' que propugna como política lingüística a nivel estatal: en primeiro lugar, "unha reforma educativa que introduza o coñecemento receptivo de todas as linguas peninsulares no conxunto de España”; en segundo lugar, unha campaña de difusión destas “en todos os ámbitos da vida social"; e aínda sinala un terceiro paso que sería "a formación plurilingüe activa das elites". O autor acecenta que a máxima representación institucional do Estado debería representar tamén na práctica a súa pluralidade lingüística e que as universidades españolas deberían contribuír na mesma dirección "animando a cursar unha introdución a estes idiomas en todas as súas especialidades ou, polo menos, nas que teñen unha proxección maior sobre a vida pública”. Mais tamén constata que de momento as cousas non discorren por esta vía, aínda que unha nova cultura da alianza e do pacto en materia lingüística no Estado, sendo un reto difícil, "constitúe unha oportunidade histórica de consecuencias incalculables" (López García-Molins 2008: 79). Certo é tamén que na Galiza o problema nin sempre reside nas persoas que viñeron de fóra, mais nos propios galegos e galegas que son vítimas deste preconcepto e que por veces rocorren ás persoas foráneas como desculpa para non utilizaren o galego. De facto, xa non é raro hoxe dar con persoas chegadas de fóra da Galiza que explicitan a vontade de seren atendidas en galego para así poderen aprender e integrárense mellor no país. 
Este preconcepto mesmo chega a se extrapolar a falantes doutras linguas minorizadas do Estado -nunca aos castelanfalantes-, que tamén son considerados maleducados por usaren a súa lingua propia. Así pois, os preconceptos derivados da consideración do uso do galego como sinal de má educación ou descortesía teñen moito que ver cos preconceptos relativos ao éuscaro e ao catalán, e moi especialmente a este último. No caso galego, xa non só se asume o preconcepto, tamén se exporta e se aplica a outras realidades lingüísicas, como acontece cos emigrantes galegos en Cataluña (Labraña 1999). Sen fundamento real, na sociedade galega funciona o tópico de os cataláns usaren a súa lingua coas persoas de fóra que non a entenden e tal preconcepto proxéctase de forma negativa sobre o propio galego, transmitindo a idea de que na Galiza non se debe caer nese comportamento e, por tanto, tamén de forma implícita, que se debe renunciar ao uso normal da lingua propia. A este respecto parece oportuno concluír coa seguinte cita:

Una manera que tienen los hablantes de una lengua de dignificarla y de mostrar que es tan útil o digna como las demás, es la de utilizarla como signo de identidad cultural y, por tanto, usarla aun en el caso de que se pueda utilizar otra lengua segunda. Por otro lado, a veces sólo somos capaces de expresarnos con total exactitud y precisión en nuestra lengua nativa. Esto lo sabe cualquier persona que haya aprendido una lengua segunda. Si la lengua de nuestro interlocutor está próxima a la nuestra, es posible que aquél utilice en ocasiones su lengua nativa, aunque conozca también la nuestra. Excepto en casos aislados de hostilidad manifiesta, esto no debe tomarse como un signo de descortesía o de enemistad, sino como un factor de sinceridad y espontaneidad. Si nosotros podemos ser espontáneos porque nos expresamos en nuestra lengua nativa, ¿por qué no admitimos muchas veces lo mismo respecto de nuestro interlocutor? (Moreno Cabrera 2006a: 256).

\subsubsection{Preconceptos relacionados coa pretensa imposición do galego}

Este grupo de preconceptos é novo, pois o abandono absoluto e mesmo a proscrición en que se mantivo o galego durante case os cinco séculos precedentes facían imposíbel que ninguén puidese pór en circulación tal discurso impositivo. É precisamente nos últimos tempos, após ese longo período de sometemento, ao se tomaren as primeiras e tímidas medidas de protección e promoción do galego, cando xorde con forza un conxunto de preconceptos que falan da imposición da lingua propia. Este discurso impositivo alcanzou especial intensidade após a posta en práctica do Decreto 124/2007 que fixaba un mínimo de 50\% da docencia en galego no ensino non universitario e nomeadamente na campaña e precampaña das últimas eleccións ao Parlamento galego.

O primeiro destes preconceptos é o de a protección legal do galego ser unha imposición dunha minoría política intolerante. Se a Constitución española 
declara o galego como lingua cooficial na Galiza, se o Estatuto de Autonomía di que é a lingua propia do país e se a Lei de Normalización Lingüística mantén que o galego é "lingua oficial das institucións da Comunidade Autónoma, da súa Administración, da Administración Local e das Entidades Públicas dependentes da Comunidade Autónoma", declarando tamén que os topónimos da Galiza terán como única forma oficial a galega, resultaría que todo iso foi imposto por unha exigua minoría parlamentar. Porén, como non podía ser doutra maneira, tanto a Constitución como o Estatuto foron promovidos e aprobados polos grandes partidos estatais, logo sancionados por referendo popular, e a Lei de Normalización Lingüística foi aprobada por unanimidade de todas as forzas políticas presentes no ano 1983 no Parlamento galego, con absoluto predominio daquela dos dous partidos estatais maioritarios, Partido Popular (PP) e Partido Socialista Obrero Español (PSOE).

Igualmente, a incorporación do galego ao sistema educativo nas últimas décadas ten posto de manifesto non poucos preconceptos sociais a respecto daquel. En primeiro lugar, tense falado da imposición do galego como materia obrigatoria, un dos preconceptos máis paradoxais porque no sistema educativo imposicións son todas as materias -Matemática, Lingua Española, Física, Inglés ou Francés etc. -. Falarmos na Galiza da imposición do galego no ensino sería como falarmos en Inglaterra da imposición do inglés ou en Castela da imposición do castelán. Tampouco resulta adecuado pretender afirmar que, así como antes se impuxo o castelán, agora se quere da mesma forma impor o galego. Non son equipárabeis as situacións: o castelán foi unha imposición a partir de finais da Idade Media porque non existía como lingua na Galiza, que se desenvolvía con total normalidade na súa propia (Freixeiro 2002). Non se pode falar de imposición dunha lingua que é a definida como propia da comunidade e que foi primeiramente a súa lingua única e logo maioritaria durante centos de anos, embora para a súa sobrevivencia sexa preciso actualmente garantirlle unha forte presenza no sistema educativo. Moreno Cabrera (2006a: 222226) xulga totalmente imprescindíbel que as comunidades lingüísticas minoritarias accedan a un espazo multicultural a través da súa propia lingua e cultura, pois tal como está a situación actual, inclusive en ámbitos económicos privilexiados como a Unión Europea, formular que as linguas minoritarias se estuden nas escolas como máis unha lingua segunda nun contorno de predominio da lingua maioritaria supón condenalas á categoría de linguas ameazadas a curto, medio ou longo prazo, segundo os casos. Após coincidir con Junyent (1998: 53) en que "l'ensenyament bilingüe que contempla l'ús de la llengua subordinada com una concessió als drets lingüístics del nen" non deixa de ser a transmisión da percepción xerarquizada das linguas, considera "absolutamente necesario conseguir una enseñanza bilingüe en la que la lengua minoritaria tenga consideración de primera lengua y no se segunda lengua" e, alén diso, tamén estima que "este protagonismo de la lengua patrimonial debe ir unido a un protagonismo de la cultura asociada a la misma". Perante unha 
situación de desigualdade, para este autor resulta evidente que se deben promover políticas que axuden de forma especial o máis débil e, de se tratar dunha situación de desequilibrio entre linguas, é obrigada a protección da minoritaria; mais, cando esta se der, de seguro que xurdirá o discurso da imposición porque "nadie renuncia al dominio de buen grado. En estos casos hablarán de imposición y de violación de derechos" (Moreno Cabrera 2006a: 224-225). Isto foi o que pasou na Galiza, primeiro cando hai case tres décadas se implantou a materia de lingua galega como obrigatoria no ensino primario e secundario, e a partir de 2007 cando un goberno bipartido PSOE-BNG promulgou un decreto que obrigaba a impartir un mínimo do $50 \%$ das materias nesta lingua. O discurso de imposición lingüística xa levaba anos en circulación na Galiza (Iglesias 2003: 287-309), embora cobrase intensidade nos últimos tempos ${ }^{18}$.

En relación co anterior, tamén se presupón un rexeitamento social á normalización do galego. E isto, aínda a recoñecer a escasa conciencia lingüística en diversos sectores da sociedade, parece ser máis un preconcepto. Se houber un amplo rexeitamento social non resulta explicábel que todos os partidos políticos que obteñen representación fagan uso do galego nas campañas electorais e inclúan a normalización lingüística nos seus programas. Posibelmente se acontece isto é porque todos os inquéritos que se publican dan altas porcentaxes de defensores do galego ${ }^{19}$. Certo que canto maior for o respaldo social, moito máis doado será normalizar a lingua; e tamén é certo que hai sectores sociais - minoritarios, mais poderosos- que se opoñen á normalización. Porén, a vontade maioritaria é favorábel, como tamén transparece nas disposicións legais emanadas da representación popular.

Outro preconcepto asociado aos anteriores é o de as crianzas galegas non gostaren da materia de Lingua Galega. No entanto, non se di nada sobre se o alumnado gosta da Matemática, do Inglés ou da Lingua Española, por exemplo. Parece como se esa fose a única materia que se debese amar para lle conceder validez académica. Aliás, semella evidente que de existiren crianzas que menosprezan o galego, estarían a proxectar o desprezo que por este idioma sentisen os seus pais ou nais e as persoas do seu contorno. Dito con outras palabras, se as crianzas tiveren preconceptos sobre

18 No ano 2009 gañou as eleccións o Partido Popular após unha campaña en parte baseada nese discurso da imposición do galego e na falta de liberdade de elección tanto dos pais e nais como das propias crianzas, e coa promesa de derrogación dese decreto.

19 O primeiro mapa sociolingüístico galego (MSG-92) recolle que o 86.6\% da populación se mostra favorábel a que se potencie o uso do galego e que o " $42.4 \%$ considera que as medidas actuais son insuficientes". Véxase unha síntese dos datos en A Nosa Terra, 1-5-97. Para unha análise completa das actitudes, competencias e usos do galego, con datos de principios da década dos noventa, véxase Seminario de Sociolingüística da RAG (1996, 1994 e 1995, respectivamente). Os datos do novo mapa sociolingüístico (MSG-04) até agora publicados non fan referencia ás actitudes, pois o volume 1 trata sobre a lingua inicial e a competencia lingüística (González 2007) e o 2 sobre os usos (González 2008). 
o galego será porque estes lles son transmitidos polos maiores, incluídos tamén os profesores.

Por outra parte, após asentar o preconcepto de o galego ser unha lingua imposta, introdúcese a idea de que o español tamén é lingua propia da Galiza. Podemos considerar este como un novísimo preconcepto, pois até agora non se cuestionara publicamente a noción de o galego ser a única lingua propia da Galiza, independentemente de que houbese persoas a favor da súa substitución polo castelán. No entanto, comeza a callar e a se estender a idea de que, como hai persoas galegas que falan español, este tamén é lingua propia dos galegos e galegas; isto é, que o castelán é tan galego como o galego. E mesmo xa xorden opinións manifestadas por escrito nos medios de comunicación que falan de que foi un erro incluír a expresión de 'lingua propia' para o galego no Estatuto de Autonomía e na Lei de Normalización Lingüística. Porén, que o castelán é tan galego como o galego é unha contradictio in terminis. Sería como dicir que o viño de Valdepeñas é tan galego como o Ribeiro porque tamén o beben persoas galegas, ou que o queixo de Burgos é tan galego como o de Arzúa pola mesma razón. Moitos habitantes de Dinamarca tamén falan inglés, mais non por iso se pode dicir que o inglés sexa tan dinamarqués como o propio dinamarqués. Unha lingua imposta na Galiza hai cinco séculos como lingua dunha reducida elite detentadora do poder, que aínda a finais do século XIX non falaba moito máis dun $10 \%$ da populación, non pode ser tan propia como aqueloutra creada no mesmo territorio e falada durante máis dun milenio pola inmensa maioría dos habitantes. De se estender o uso do inglés como terceira lingua de comunicación na Galiza ou como segunda na comunidade de Madrid, tampouco se poderá dicir que é tan galego como o galego ou tan español como o español. Porque as linguas tamén achegan identidade e a identidade galega maniféstase no idioma como valor primordial. Para Fasold (1996: 361) a conservación da lingua é un sinal claro de que existe conciencia de identidade e Fishman (1997: 26) afirma que o "mantemento lingüístico é unha función do mantemento da pertenza a un grupo ou da lealdade grupal". Tal función identificadora só a pode desempeñar na Galiza o galego. Por iso os representantes do pobo o declararon a súa lingua propia.

\subsubsection{A caracterización pexorativa do galego e a (in)competencia dos seus falantes}

Este é outro grupo de preconceptos vellos e novos que empece o proceso de normalización e que costuma presentarse so diferentes formulacións. Uns céntranse na consideración do galego como lingua vulgar ou como propia da xente idosa, outros consideran os falantes como incompetentes ou pouco coñecedores do seu idioma, ou cuestionan o estándar. O vello preconcepto do galego como lingua ruda ou fea ten unhas evidentes causas históricas, que non son outras máis que as derivadas do sometemento da Galiza a Castela a fins da Idade Media e as consecuencias de 
miseria e pobreza que levaron moitos galegos a teren de marchar da súa terra na procura da subsistencia, realizando os traballos máis duros e a soportaren burlas e desprezos, como pon en relevo a literatura española daquela altura (Caramés 1993). Do desprezo pola Galiza e polas súas xentes pasouse doadamente á ridiculización da súa fala, que iría adquirindo o estigma de ser propia de persoas rudas, brutas e ignorantes. E iso acabaría por menoscabar o prestixio do galego entre os propios falantes ${ }^{20}$.

A consideración do galego como lingua non válida para a xente nova contribúe tamén para a súa caracterización pexorativa. O desprestixio do idioma levou moitos pais a pretenderen aprenderlles o castelán aos seus fillos, iniciándose desa forma a ruptura na transmisión interxeracional. Así, o galego foi adquirindo máis outro estigma, ser unha lingua de vellos e impropia para os tempos modernos. Este preconcepto está na actualidade moi instalado entre as propias persoas idosas, que en ocasións non ven ben que as crianzas sexan educadas en galego. Acontece que a caracterización do galego como fala ruda e fea convérteo, consecuentemente, en inadecuado para ser usado polas crianzas, mostrándose máis unha vez a forte relación entre todos os preconceptos. O galego pode aceptarse doadamente na taberna, nos traballos da pesca ou nas estadas das obras, mais non na vida dos nenos e nenas, esperanza de futuro que a este idioma se lle pretende negar por o considerar preconceptuosamente lingua das persoas maiores. Isto é moi negativo para o seu futuro, pois cando un idioma deixa de ter falantes entre a xente nova é que camiña cara á extinción (Crystal 2003: 120-122).

Por outra parte, o preconcepto do galego normativo como lingua artificial ${ }^{21}$ convértese en máis unha demostración de que no fondo dos diferentes preconceptos subxace unha mesma causa: ao tempo que se despreza o galego por ser propio de xente rústica e ignorante, tamén se critican os intentos de elaboración e uso dun galego culto. Existe, así, o tópico de afirmar que o galego que se ensina nos centros docentes ou que se utiliza nos medios de comunicación non é o galego que fala o pobo labrego e mariñeiro, verdadeiro posuidor e transmisor do idioma. Porén, nas escolas de todos os países ensínase unha lingua estándar, convencional, que trata de servir de factor unificador das variantes da fala que se dan en todos os idiomas, pois a variedade é inseparábel das linguas humanas "y su misma esencia está en esa variedad" (Moreno Cabrera 2006a: 50). Fálase de que só en Londres existen unhas

20 Disto é un bo exemplo a anedota que narra Dieste (1971: 33-35) no seu discurso de ingreso na Academia: a camiñar polo monte atópase cunhas raparigas que falan galego, mais que din escuela en vez de escola e, ao lles preguntar a razón, elas responden que porque a palabra castelá é máis fermosa.

21 Dunha ou doutra forma este preconcepto ponse en relevo nas investigacións de Kabatek (2000), Iglesias Álvarez (2003) ou González (2003), onde mesmo as persoas novas adoitan xulgar negativamente o uso do galego normativo por se non corresponder coa fala espontánea dos galegofalantes tradicionais. 
oito variedades de inglés; e hai variantes no español e tamén no galego. Mais este posúe mesmo unha grande unidade interna, por riba das lóxicas variantes, aínda que a situación histórica anómala por que pasou fai hoxe necesario un proceso de estandarización xa practicamente acabado, proceso que outras linguas realizaron hai moito tempo. Fica claro que o galego que falan os labregos e mariñeiros é auténtico galego, mais non se pode trasladar sen máis ese modelo de lingua á escola ou á televisión, porque a vida moderna non se reduce só ao mundo rural e a lingua ten de se adaptar tamén a ela, ao mundo urbano, científico, técnico etc.

No entanto, para falar unha lingua non é preciso un dominio absoluto do rexistro culto. Non se pode identificar lingua con gramática ou con norma culta, pois isto tamén é un preconcepto máis propiamente social do que lingüístico (Bagno 2005: 16). A lingua é variedade e vive nos seus falantes; por iso toda aquela persoa que estiver en contacto directo coa sociedade galega adquirirá espontaneamente o dominio da lingua e a capacidade de se expresar nela ${ }^{22}$. Nun contexto sociolingüístico de normalidade cómpre insistir en que a lingua estándar propiamente non existe como lingua real (Moreno Cabrera 2006a: 51) e que non se pode sacralizar a norma nin moito menos descualificar os falantes por se non axustaren sempre a ela, pois isto mesmo se converte en factor de exclusión social (Bagno 2001, 2003, 2005). Tales aseveracións son perfectamente válidas e aplicábeis tamén ás linguas minorizadas como o galego. Porén, existe unha particularidade neste caso: sendo lexítimas e totalmente respectábeis todas as manifestacións da fala espontánea, o forte proceso de erosión interna do galego -a súa castelanización avanzada- dálle ao estándar un valor acrecentado como elemento preciso e imprescindíbel para evitar a morte da lingua por disolución ou converxencia coa lingua dominante. Unha persoa tan defensora da diversidade de linguas e da diversidade na lingua e ao mesmo tempo desmitificadora da norma e contraria á noción de 'pureza' lingüística, o profesor Moreno Cabrera (2006a: 248), admite en situacións de dominio esmagador dunha lingua sobre outra que "una cierta exigencia de purismo" pode "ser positiva y debe considerarse necesaria para la supervivencia de la lengua amenazada". Eis o caso do galego.

Ora, defender a necesidade de descastelanización do galego non é o mesmo que dar apoio a outro preconcepto ás veces utilizado para xustificar a despreocupación polo seu uso, aquel de quen di non falar galego porque non o sabe falar ben, cuestionando así a propia competencia lingüística. Unha lingua nunca se chega a falar ben de todo, pois sempre se pode mellorar o seu uso, mais por principio a unha persoa galega ambientalmente en contacto co galego debe presupórselle a competencia para o usar. A máxima expresión deste preconcepto é presumir de non saber falar a lingua propia do país en que un naceu e viviu. E isto aconteceu e aínda acontece.

22 Xa Rafael Dieste (1971: 19) deixou escrito: "Unha academia viva anda polos camiños, antre o monte e o mar". 
Xa o denunciaba Pintos (1853: 37) no século XIX (E catro farafulliñas/ Se gaban de non sabelo) e mesmo se deixa ver nos séculos escuros ${ }^{23}$. Porén, nunha situación de forte interferencia como a que sofre o galego, alén de o falar, é preciso un esforzo complementar para depurar os castelanismos que ameazan o seu futuro.

\subsubsection{O galego como marca ideolóxica ou profesional}

É este un grupo de novos preconceptos xurdidos nas últimas décadas como consecuencia da incorporación do galego á vida pública, en especial á actividade política e educativa. Pode manifestarse de diversas maneiras, a primeira presentándoo como lingua marcada politicamente. Aínda que a asociación entre lingua e política vén xa de vello porque na realidade ambas son indisociábeis, un dos novos preconceptos aparecidos na transición do réxime ditatorial á democracia e aínda moi vigorante na actualidade é o de considerar o uso consciente do galego como marca ideolóxica. A presenza na sociedade galega actual de persoas conscientes da importancia da lingua e da necesidade do seu uso exemplar en todos os contextos, isto é, de persoas con conciencia política no uso do idioma, moitas delas criadas no medio urbano e educadas en español, fixo introducir unha nova connotación: o galego como símbolo identificador dunha ideoloxía política nacionalista. Esta identificación cunha ideoloxía determinada ou cunhas siglas políticas concretas non é, de certo, positiva para o galego, pois mellor sería que o seu uso e defensa fose unha característica distintiva de todas elas. Face ao discurso de apropiación da lingua por parte dos nacionalistas que os partidos de ámbito estatal adoitan utilizar, preséntase como eficaz o convite a que estes tamén se apropien dela e se convertan en abandeirados do seu uso e defensa. Mais aínda son necesarios moitos esforzos para comprometer todas as forzas políticas e sociais na defensa do galego.

Face a esa marca de politización que se lle adxudica ao galego, o español aparece como lingua neutra no comercio, na hostalaría e noutros ámbitos da actividade socioeconómica. Neles resulta habitual expresárense en castelán persoas que logo na súa vida particular falan galego, o cal significa que o uso desta lingua está connotado e, por tanto, a tendencia é a usar unha lingua neutra, o español, supostamente non marcada social ou politicamente. Tal consideración do español como a lingua non marcada na relación comercial ou na hostalaría é un preconcepto moi daniño para o galego, pois ninguén gosta de ser caracterizado, ou inclusive estigmatizado, social ou politicamente, pola lingua que utiliza. Mesmo se podería dicir que unha lingua fortemente connotada dificilmente pode chegar a ser unha lingua normalizada.

23 O romance de José Guerrero Lasso de la Vega, de 1697, comeza así: Señores, eu ben quixera/ escribir, pero non sei/ nin o romance galego; i é natural non saber (Os séculos escuros e a Ilustración galega. Antoloxía, A Nosa Literatura 7, AS-PG / A Nosa Terra, 1996, p. 44). 
Noutras ocasións asóciase o uso consciente e correcto do galego coa condición de profesor ou profesora de Lingua Galega, de modo que aquel non só revelaría a orixe, a condición social e a ideoloxía política, mais tamén a profesión. Ao mesmo tempo, no fondo desde preconcepto subxace a idea de que só poden, deben ou teñen interese en falaren ben o galego aquelas persoas que profesionalmente viven del, ficando todas as demais eximidas de tal responsabilidade. Evidentemente, e como se acaba de ver, estas connotacións non resultan positivas para unha lingua con vocación de normalidade. Se axir como elemento marcado ou connotado na comunicación, terá máis difícil ser unha lingua con perspectivas de futuro, pois polo xeral a xente non gosta de que se coñezan as súas características persoais ou íntimas e maioritariamente, se tiver opción, procurará escoller aquela lingua que as non descubra. Sempre que se estabelecer unha oposición entre un termo marcado e outro non marcado, será este o que vai predominar; pasa, por exemplo, na gramática coa oposición de xénero feminino -marcado- e masculino -non marcado- e pasará tamén, por esta vía, na sociedade coa oposición entre galego -lingua marcada - e castelán - lingua non marcada-. Así como o movemento feminista loita contra esa discriminación de xénero e hoxe xa non se considera politicamente correcta, o movemento galeguista - de defensa do galego- tamén deberá loitar contra a identificación do galego só con determinados ámbitos da vida social -ruralismo, clase social baixa, ideoloxía nacionalista, profesorado da materia etc. -, na procura de ser recoñecido como lingua posíbel e presente en todos os ámbitos, isto é, para que sexa unha lingua non connotada ou moito menos connotada do que agora é.

Ao mesmo tempo, tamén acontece que cando unha persoa utiliza un modelo de galego depurado e máis acorde coas solucións comúns e tradicionais do sistema lingüístico en que está inserido, é cualificado de lusista ou mesmo se afirma que fala portugués; sería o caso, por exemplo, de algúen que dixese: Esta sexta feira vou apañar un carro e visitar o elevador do monte de San Pedro. Mais nada hai nesta expresión que non sexa auténtico e puro galego. Revélase así a existencia de máis un preconcepto ligado á competencia e ao modelo lingüístico, e que consiste no rexeitamento do portugués ou 'lusofobia', a outra face da 'galegofobia', como afirma García Negro (2009: 153-167). A estrañeza ou mesmo repudio que causaría o enunciado antecitado tornaríase en asunción compracente só con algunhas mudanzas, a pesar de conteren evidentes incorreccións: Este viernes vou a coller un coche e visitar o ascensor do monte de San Pedro. Por una visión preconceptuosa da lingua asúmense con naturalidade os españolismos ou as formas coincidentes co español, mais rexéitanse os 'lusismos' -no fondo tamén galeguismos- ou as formas coincidentes co portugués. Eis a perversión dos preconceptos. 


\section{Conclusión}

Os preconceptos lingüísticos son unha manifestación do racismo aplicado ás linguas e aos seus falantes, afectan fundamentalmente os idiomas minorizados, provocan discriminación e reflicten intolerancia. Existiron desde a antigüidade e continúan a axir na actualidade, onde moitas linguas faladas en todo o mundo se senten ameazadas por eles. Entre estas está o galego, vítima secular de vellos preconceptos e vítima tamén doutros novos xurdidos como consecuencia das mudanzas sociopolíticas que se produciron na Galiza e no Estado español nas últimas décadas, ben como nun novo contexto mundial de globalización. Moitos destes preconceptos parecen máis propios dunha época anterior en que a sociedade galega tiña negados os máis elementais dereitos lingüísticos. No entanto, non resulta difícil constatar que aínda están a vigorar agora, cando o galego xa leva anos incorporado ao sistema educativo e cando conseguiu certa presenza pública, para alén de protección legal. De aí a necesidade de profundar no seu coñecemento e de os combater con eficacia.

\section{Referencias bibliográficas}

Allport, G. W. (1962): La naturaleza del prejuicio (Buenos Aires: EUDEBA).

Alvar, M. (1971): “Bilingüismo e integración”, Revista Española de Lingüística, 1/1, 25-57.

Baggioni, D. (2004): Linguas e nacións na Europa (Santiago de Compostela: Laiovento).

Bagno, M. (2001) [2000]: Dramática da língua portuguesa. Tradição gramatical, mídia \& exclusão social (São Paulo: Loyola).

Bagno, M. (2003) [1999]: Preconceito lingüístico. O que é, como se faz (São Paulo: Loyola).

Bagno, M. (2005) [2003]: A norma oculta. Lingua \& poder na sociedade brasileira (São Paulo: Parábola).

Baker, C. (1992): Attitudes and Language (Clevedon: Multilingual Matters).

Calvet, L.-J. (1993): Lingüística e colonialismo. Pequeno tratado de Glotofaxia (Santiago de Compostela: Laiovento).

Caramés García, X. (1993): A imaxe de Galicia e os galegos na literatura castelá (Vigo: Galaxia).

Castelao, A. D. Rodríguez (1961): Sempre en Galiza (Buenos Aires: Edición “As Burgas").

Costas, X. H. (2002): Guía das linguas de Europa (Santiago de Compostela: Edicións Positivas). 
Crystal, D. (2000): Language Death (Cambridge: Cambridge University Press). Citado pola edición galega: A morte das linguas. Vigo, Galaxia, 2003.

Curros Enríquez, M. (1886): Aires da miña terra (Coruña: Latorre y Martínez Editores).

Dieste, R. (1971): A vontade de estilo na fala popular (Coruña: Ediciós do Castro).

Dieste, R. (1981): Antre a terra e o ceo (Sada / A Coruña: O Castro).

Fasold, R. W.(1996): La sociolingüistica de la sociedad. Introducción a la sociolingüística (Madrid: Visor).

Fishman, J. (1997): O mantemento e o cambio de lingua coma campo de investigación. En Lynch. Documentos de trabajo, 7 (Valencia: Centro de Estudios sobre Comunicación Interlingüística e Intercultural).

Freixeiro Mato, X. R. (2002) [1997]: Lingua galega: normalidade e conflito (Santiago de Compostela: Laiovento).

Freixeiro Mato, X. R. (2006): Lingua, nación e identidade (Santiago de Compostela: Laiovento).

Garcia Negro, M. P. (1993): Sempre en Galego (Santiago de Compostela: Laiovento).

García Negro, M. P. (2009): De fala a lingua: un proceso inacabado (Santiago de Compostela: Laiovento).

González González, M. (dir.) (2003): O galego segundo a mocidade. Unha achega ás actitudes e discursos sociais baseada en técnicas experimentais e cualitativas (A Coruña: Real Academia Galega).

González González, M. (dir.) (2007): Mapa sociolingüistico de Galicia 2004. Vol. 1: Lingua inicial e competencia lingüística en Galicia (A Coruña: Real Academia Galega).

González González, M. (dir.) (2008): Mapa sociolingüistico de Galicia 2004. Vol. 2: Usos lingüísticos en Galicia (A Coruña: Real Academia Galega).

Iglesias Álvarez, A. (1999): "O poder explicativo e predictivo das actitudes lingüísticas”, Verba, 26: 273-307.

Iglesias Álvarez, A. (2003) [2002]: Falar galego: "No veo por qué". Aproximación cualitativa á situación sociolingüistica de Galicia (Vigo: Galaxia).

Iglesias Álvarez, A. (2007): “Os preconceptos lingüísticos segundo a idade”, en Méndez López, I. / Sánchez Pérez, A. (eds.), Lingua e Idade. III Xornadas sobre Lingua e Usos: 165-182 (A Coruña: Servizo de Publicacións da Universidade da Coruña).

Junyent, C. (1986): Les llengües d'Africa (Barcelona: Empúries).

Junyent, C. (1998): Contra la planificació. Una proposta ecológica (Barcelona: Empùries). 
Kabatek, J. (2000): Os falantes como lingüistas. Tradición, innovación e interferencias no galego actual (Vigo: Xerais).

Labraña, S. (1999): "Prexuízos lingüísticos e identificación social”, en Álvarez, R. I Vilavedra, D. (coords.), Cinguidos por unha arela común: Homenaxe ó profesor Xesús Alonso Montero. Vol. 1: $519-532$ (Santiago de Compostela: Universidade).

Lapesa, R. (1962) [1942]: Historia de la lengua española (Madrid: Escelicer).

Leite, M. Quadros (2008): Preconceito e intolerância na linguagem (São Paulo: Contexto).

Lodares, J. R. (2000): El paraíso políglota. Historias de lenguas en la España moderna contadas sin prejuicios (Madrid: Taurus).

López García, A. (2007): "La polisemia del término común aplicado a la lengua española”, en Schrader-Kniffki, M. / Morgenthaler García, L. (eds.), La Romania en interacción: entre historia, contacto y politica: 571-590 (Madrid: VervuertIberoamericana).

López García-Molins, A. (2008): “Cara ao plurilingüismo equitativo. Por unha política lingüística do Estado”, Grial, 179: 68-79.

Lorenzo Suárez, A. M. (2005): "Planificación lingüística de baixa intensidade: o caso galego", Cadernos de Lingua, 27: 37-59.

Monteagudo, H. / Bouzada, X. M. (coords.) (2002): O proceso de normalización do idioma galego (1980-2000). Vol. 1. Política lingüistica: análise e perspectivas (Santiago de Compostela: Consello da Cultura Galega).

Moreno Cabrera, J. C. (2006a) [2000]: La dignidad e igualdad de las lenguas. Crítica de la discriminación lingüística (Madrid: Alianza Editorial).

Moreno Cabrera, J. C. (2006b): De Babel a Pentecostés. Manifiesto plurilingüista (Barcelona: Horsori Editorial).

Moreno Cabrera, J. C. (2008): El nacionalismo lingüístico (Barcelona: Península).

Moure, T. (2005): Outro idioma é posible. Na procura dunha lingua para a humanidade (Vigo: Galaxia).

Moure, T. (2006): "É o inglés imprescindible para a investigación? A necesidade de recoñecermos o plurilingüismo", en Servizo de Normalización Lingüística da Universidade da Coruña (ed.), Lingua e Investigación. II Xornadas sobre Lingua e Usos: 93-108 (A Coruña: Servizo de Publicacións da Universidade da Coruña).

Nettle, D. / Romaine, S. (2000): Vanishing voices. The extinction of the world's languages (Oxford: University Press).

Ninyoles, R. L. (1997): Idioma i prejudici (València: Eliseu Climent). 
Ninyoles, R. L. (2005): Idioma e poder social (Santiago de Compostela: Laiovento).

Núñez Singala, M. (2009): En galego, por que non? Contra os prexuízos e as simplificacións sobre a lingua galega (Vigo: Galaxia).

Phillipson, R. (1992): Linguistic Imperialism (Oxford: Oxford University Press).

Pintos, X. M. (1853): A Gaita Gallega tocada po lo gaiteiro, ou sea Carta de Cristus... (Pontevedra: Imprenta de José y Primitivo Vilas).

Rei-Doval, G. (2007): A lingua galega na cidade no século XX. Unha aproximación sociolingüística (Vigo: Xerais).

Roca, I. M. (1997): "On language death and language survival: the case of Galician", en Fernández Salgado, B. (ed.), Proceedings of the 4th International Conference of Galician Studies / Actas do IV Congreso Internacional de Estudios Galegos. Vol. 1: 449-489 (Oxford: Oxford Centre for Galician Studies).

Rodríguez Alonso, M. (2004): O españolismo lingüistico (A Coruña: Espiral Maior).

Salvador, G. (1987): Lengua española y lenguas de España (Barcelona: Ariel).

Seminario de Sociolingüística (1994): Lingua inicial e competencia lingüística en Galicia (A Coruña: Real Academia Galega).

Seminario de Sociolingüística (1995): Usos lingüísticos en Galicia (A Coruña: Real Academia Galega).

Seminario de Sociolingüística (1996): Actitudes lingüisticas en Galicia (A Coruña: Real Academia Galega).

Sende, S. (2007): Made in Galiza (Vigo: Galaxia).

Seriot, P. (1984): “Pourquoi la langue russe est-elle grande?", Essais sur le Discours Soviétique, 4: 57-89.

Skutnabb-Kangas, T. (2000): Linguistic Genocide in Education - or Worldwide Diversity and Human Rights? (London: Lawrence Erlbaum Associates).

Tuson, J. (1990): Mal de linguas. Arredor dos prexuícios lingüísticos. Trad. de Xulio C. Sousa (Vigo: Ir Indo). 